\title{
Shunji WATARI: Studies on the fossil woods from the Tertiary of Japan. VI. Meliosma Oldhami Miquel from the Miocene of Simane. ${ }^{1)}$
}

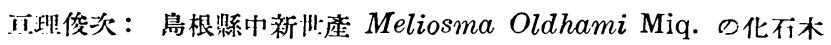

Received 19. June, 1949.

Among a considerable number of silicified woods obtained by the writer at the beach of Taziri, Nima Village, Simane Prefecture (the Miocene)2), there are several specimens (Nos. 64505-64510) which show some remarkable features on the weathering surfaces. Boundaries of the growth rings deliniated by fine concentric lines and closely spaced, fairly brcad, rays are plainly visible even to the naked eye, and the sparsely distributed pores are obvious with a hand-lens. The largest measures ca. $30 \mathrm{~cm}$. in diameter. In all specimens, prescrvation of the internal structures is fairly good, excepting occasional deformation in the thicker walls of the fiber tracheids and ray cells.

Description. Growth rings distinct, deliniated by one to a few layers of flattened elements, breadth variable, usually fairly broad. Wood diffuse-porous. Vessels solitary, in multiples of $2-4$, or in circular, nestlike, groups of a few to 10 or more, the last condition being usually more prevailed in the late wood, but fairly variable in different increments or specimens. Solitary vessels and groups of vessels scarce, evenly distributed throughout increment, 1-8 per square mm. Solitary vess:ls radially elongated oval, the largest usually 140-200 and 150-220 microns in tangential and radial diameters respectively (the latter measuring 550 microns in an example); thin-walled; length of vessel segments $230-1300$, mostly $600-1000$, microns ; perforation. plates slunting at a variable angle, or not infrequently forming no definite end walls owing to lateral alinement of vessel segments, the perforations being placed on their lateral side; perforations predominantly scalariform, cross bars with 1-11 (mostly 2-8, exceptionally up to 28), feeble to moderately thickened, occasionally ramified and widely spaced; intervessel pitting opposite or alternate, the pits usually angular by mutual contact, 4-8 microns in diameter, with horizontally elongated lenticular to elliptical apertures; spiral thickenings or striations entirely absent; thin-walled tyloses occasionally present. Fiber tracheids of two kinds; (1), thin-walled, non-septate, regularly arranged, elements with large lumens, forming ground mass of the increments; (2), rather thick-walled, mostly septate, ones, forming a $f \in w$ to several layers of ring margins and aliform sheath about a vessel or group of $x \in$ ssels, the latter frequently confluent, especially in the late wood, to form characteristic tangential bands or oblique anastomosing patterns; pits small but apparently bordered, with vertical, elliptical to lenticular, apertures. Paratracheal parenchyma obvious, forming 1 layer of incomplete sheath about a vessel or group of vessels; individual elements 20-50 microns in the largest diameter, 40-200 microns in length, thin-walled; pitting between adjacent vessels half-bordered, frequently a few circular or oval pits on the vessel side open into a horizontally elongated

1) Contributions from the Divisions of Plant-Morphology and of Genetics, Botanical Institute, Faculty of Seience, University of Tokyo, No. 327.

2) From the same locality the writer reported in an earlier paper (;948) the occurrence of Glyptostroboxylon cunninghamioides Watari which is closely related to a living Cunninghamia. 
narrow elliptical area, thus forming a scalariform pitting on the parenchyma side; crystalliferous elements absent. Rays apparently heterogeneous, uniseriate and multiseriate, very high. Uniseriate rays linear, consisting entirely of upright cells or mixed with procumbents; up to ¿3 cells high. Multiseriate rays 2-8(9) cells wide, consisting of median procumbents and marginal wings of upright cells of 1 to several cells high; occasionally flanked by incomplete sheath cells; very high, the tallest more than 100 cells or $3.6 \mathrm{~mm}$. in height. Procumbent cells polygonal in tangential section, 20-60 microns in diameter; upright cells rectangular to oval, marginals frequently with tapering ends, 12-32 and 35-120 microns in tangential and vertical diameters respectively. All walls slightly thickened and densely pitted, pitting between adjacent vessels half-bordered, form and size being nearly identical with the intervessel pitting. Crystalliferous elements not present.

Discussion. In the identification of this diffuse-porous wood, there are many remarkable characters: i.e., scarceness of vessels or groups of vessels in an unit square; frequent presence of circular, nestlike, groups of vessels; predominant occurrence of scalariform perforations with relatively small number of cross bars; the characteristic arrang $€$ m $€$ nt of the normal thin-walled and thick-walled septate fiber tracheids; occurrence of a layer of incomplete vasicentric parenchyma; presence of very high rays reaching 8 or 9 cells in width; abundance of the fiber tracheids and ray cells provided with large lumens which indicate soft and lightness of the wood.

After precise examination on these characteristics, the writer reached to the conclusion that the woods exhibiting such features are nothing but two species belonging to the section Pinnatae of Meliosma, viz., M. Oldhami Maxim. from Corea and the Tusima Islands. Japan, and $M$. rhoifolia Maxim. from the Luchoo Archipelago and Formosa. In comparing the anatomical descriptions on the woods of $M$. Oldhami Maxim. (Yamabayashi, 1939) and $M$. rhoifolia Maxim. (Kanehira, 1921, 1926), only the distinction, besides some slight numerical differences in the measurements of elements, lies in rare occurrence of the terminal parenchyma in the former species, while it is not described in the latter. If we understand that this character is unfortunately overlooked or ignored by Dr. Kanehira, the separation of both species by the anatomical characters seems to virtually impossible. In a $f \in w$ specimens of the fossil, the presence of the elements is rarely suggested, but it is uncertain, the distinction of such an element in a cross ssction being rather difficult even when the deformation of walls are fairly slight as in the case of present fossil, and, in the tangential ssction, the

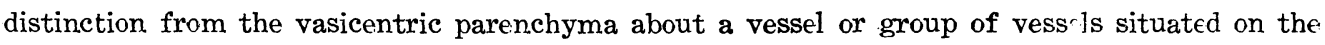
terminal or beginning of the increments is actually very difficult. However, considering the marked similarities in other details, there seems to be no doubt that this fossil agrees with these living spacies. On the other hand, the difference in the external morphological characteristics on which the distinction of these two species are based seem rather very slight. According to the opinion of Dr. Koidzumi (1943), M. Oldhami Maxim., M. rhoifolia Maxim. and $M$. sinensis Nakai belong to a single species, and he adopted $M$. Oldhami Miquel from the nomentclatorial stand point. Under the circumstances, it would be best that I adopt here Meliosma Oldhami Miquel for this fossil in the sense of Dr. Koidzumi.

A closely related species $M$. hachijoensis Nakai, endemic to Hatijo Island, Japan, also shows a considerable resemblance with the present fossil, but, so far as the writer's obssrvations concern, the width of rays never exceeds 6 cells and the occurrence of the porous perforations 
are fairly frequent (in a material they reach 49 per cent in at random observations on 100 perforation plates). According to the description. by Moll and Janssonius (1908), M. ferruginea Blume from Java and Borneo shows some resemblance, but it is apparently differed from this fossil in possessing narrower rays, in that the pores occur mostly in multiples, and in the possession of parenchyma in one or more layers of complete: sheath about vessels. In. the species belonging to the other section, i.e., Simplicifolia, the differences are far more apparent. Some of them (e.g., M. tenuis Maxim., M. callicarpaefolia Hayata, M. squamulata Hance, etc.) are characterized by mostly solitary or short multiples of vessels and by the numerous cross bars of the scalariform perforations, while in others (e.g., M. myriantha Sieb. $\in$ t Zucc.,

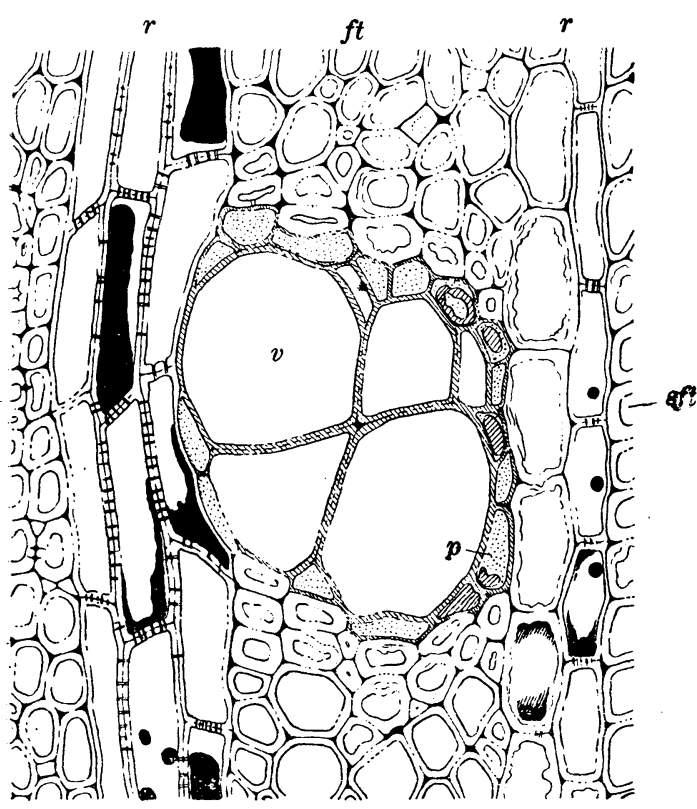

A

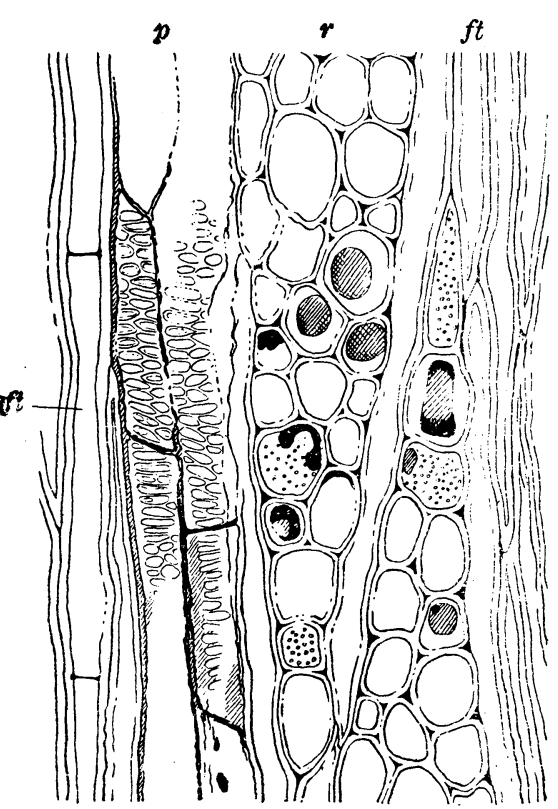

B

Text-fig. A, cross section of a small part of the early wood including a group of vessels. B, tangential section showing two rays, etc. $v$, vessels ; $r$, rays ; $p$, vasicentric parenchyma; $f t$, thin-walled fiber tracheids; $s f t$, vasicentric septate fiber tracheids with thicker walls. $\times 200$.

M. rigida Sieb. et Zucc., etc.), by the frequent occurrence of a radial series of a few to several vessels which form not a multiple but a chain consisting of an alternation of vessels and parenchymatous elements; morever, in all species the maximum width of rays is always narrower than that of the present fossil.

Remains of the pinnately leaved Meliosma have hitherto been recorded neither from the Mesozoic nor Tertiary deposits of Japan. The occurrence of the fossil woods of such Meliosma is undoubtedly a matter of particular importance, since the exact identification by a fossil leaf, especially in the case of a detached leaflet, seems almost impossible owing to its common morphological characteristics which are widely prevailed among the families with remote affinities. 


\section{Explanation of Plate (Pl. II)}

A, cross section including a boundary of growth rings. $\times 45$.

B, tangential section, a ray in the center reaching 7 or 8 cells in width. $\times 45$.

C, cross saction showing a group of vessels, a few rays, etc. $\times 130$.

D, radial səction showing two scalariform perforations and intervessel pitting. $\times 200$.

E, radial section showing pitting between a ray and two vessels; at the top, part of a $f \in \mathbb{w}$ widely spaced cross bars are sэen. $\times 200$.

\section{References}

Kanehira, R. (1921): Anatomical characters and identification of Formosan woods. Taihoku, Formosa.

(1926): Anatomical characters and identification of important woods of the Japanese Empire. Taihoku, Formosa. (Japanese).

Koidzumi, G. (1943) : Acta Phytotax. et Geobot., 12(2), 116-117.

Moll, J. W. and H. H. Janssonius (1908): Mikrographie des Holzes der auf Java vorkommenden Baumarten. II. Bd.

Watari, S. (1948) : Bot. Mag., Tokyo, 61, 11-14.

Yamabayashi, N. (1938) : Identification of Corean woods. Bull. Forest Expær. Stat. (Corea), No. 27.

\section{和 文 摘 要}

昭和 24 年春孝の植物學會大會の席上, 島根縣雨摩郡仁萬村字田尻の中新世層から Liquidambar, Tuglans, Quercus と共に Meliosma rhoifolia Maxim. に類似する化石木が多童することを述べたが (講演要旨, 本誌 62 兊, p. 68, 1949), 構滥の主要默は次の通りである。散孔材で, 導管がしばしば蜂巢 狀に集合し，呀孔は多く階段狀（横線 1-11）で時に導管の侧壁に位することがある。繊維狀假導管に 2 種類あり，一つはやや厚膜で隔膜を具え，導管周を園繞するが切線方向に流れて他群と互に連つて年輪に 平行する特有の橫縞を作り，他は薄膜で隔膜を缺く。柔組織は不完全な周圍狀。髓線は暴性，幅 9 細胞 幅に及び高さ時に $3.6 \mathrm{~mm}$ に及ぶ。この特徽は Meliosma 中 Pinnatae 節のもの以外のものにの及見ら れ，殊に M. rhoifolia や M. Oldhami とよく符合するが，この兩種は材構浩もよく一致し，既に小泉 博士 (1943) は外部形態的差異の僅小であることに基き同一種 M. Oldhami Miq. として报つている。 題記の學名はこの意見に從つたものである。な活同地からに既に Glyptostroboxylon cunninghamioides. Watari (1948) が報告されている。 

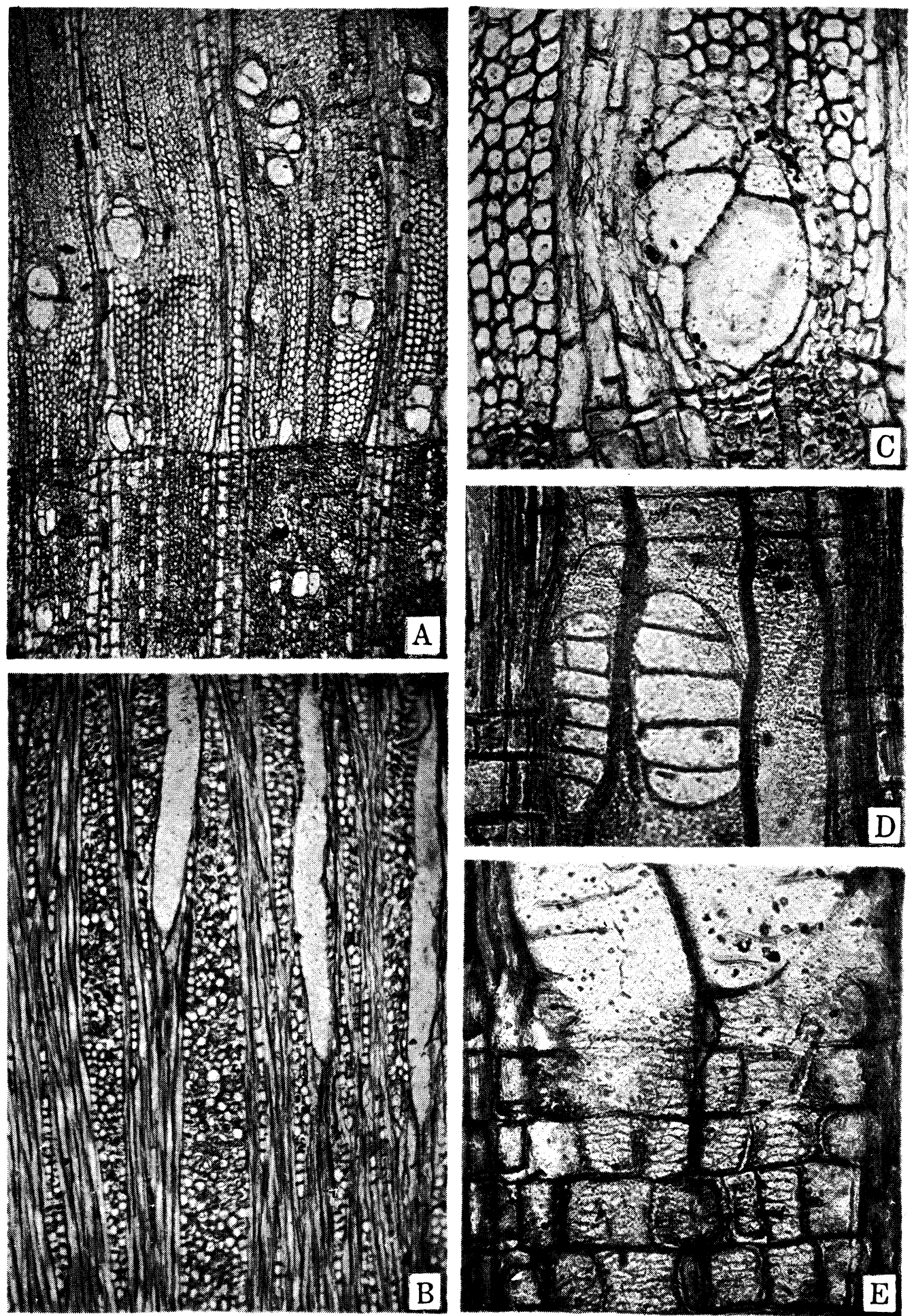

S. Watari : Meliosma Oldhami Miq. from the Miocene of Simane. 